\title{
Redaksioneel: Sarel van der Merwe
}

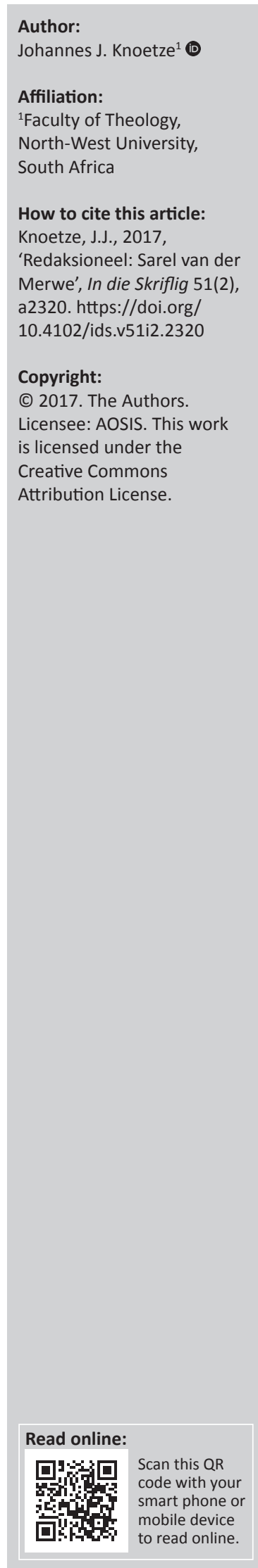

Hierdie publikasie is die resultaat van 11 navorsingsartikels waarin daar oor die invloed van die missio Dei vanuit verskillende vakgebiede en perspektiewe besin word. Die meeste van die outeurs is kollegas van prof. Sarel van der Merwe of is op verskillende maniere deur sy onblusbare passie vir die missio Dei beïnvloed. Met die samestelling van die publikasie het die veelkleurige rykdom van die missio Dei vanuit die verskillende vakgebiede na vore getree. Die verskeidenheid temas het die uniekheid van elke artikel beklemtoon. Drie van die elf artikels is in Afrikaans en die res in Engels geskryf.

Vanuit die Ou Testament skryf Herrie van Rooy 'n Afrikaanse artikel met die titel 'Die missio Dei en die bestudering van die Ou Testament'. Hierdie artikel fokus veral op die rol en die boodskap van die Ou Testament vir die sending van die kerk asook vir teologiese opleiding. Nadat sekere aspekte van die missio Dei uitgelig is en voorbeelde vanuit die Ou Testament gegee is, word die boek Esegiël gebruik om die missionale taak van die kerk te beskryf.

Vier van die artikels kom vanuit Sarel se kundigheidsveld, naamlik missiologie. Hannes Knoetze gee 'n historiese oorsig oor die ontwikkeling van missiologie as vakgebied oor die afgelope 100 jaar aan die hand van die groot sendingkonferensies. Hierdie artikel, getiteld 'A long walk to obedience: Missiology and mission under scrutiny (1910-2010)', wil die volgende vraag beantwoord: Wat beteken dit om missiologies gehoorsaam te wees in 'n gebroke en getraumatiseerde wêreld? In Pieter Verster se Afrikaanse artikel met die titel ‘Die missionale kerk in informele behuisingsgemeenskappe' word die geweldige sosiale uitdagings wat die vinnige verstedeliking meebring bespreek aan die hand van die holistiese aard van die missio Dei. Die sentraliteit van die verkondiging van Jesus Christus as hoop om die gemeenskappe te bemagtig, word beklemtoon. Nog 'n Afrikaanse artikel uit die missiologie is dié van Johan Erasmus en Henk Stoker met die titel ‘Die noodsaak van kulturele interaksie in Apologetiek: Handelinge 17:16-32 as motivering' waarin aandag aan die sekulêre teenoor die heilige dualisme geskenk word. Hierdie artikel argumenteer dat om kultureel effektief te wees in die kommunikasie van die evangelie moet die apologetiek van beelde en uitdrukkings gebruik maak van dít wat aan die teikengehoor bekend is. Hier word veral na die kunste verwys en hoe sekere films die apologeet kan help. Handelinge 17 word as voorbeeld gebruik van hoe Paulus die Griekse wêreldbeeld ondergeskik aan die monoteïstiese Christelike wêreldbeeld stel. 'n Tweede artikel in die apologetiek deur Henk Stoker en Paul Derengowski, getiteld 'A discussion about the version of the Bible available to Muhammad', handel oor die feit dat van Moslems verwag word om die Bybel te glo volgens Surah 2:4. Hierdie artikel tree in gesprek met die Moslem apologete wat hierdie mandaat verwerp, aangesien die Bybel volgens hulle korrup is.

Dit is welbekend dat die missio Dei ten nouste met die verbond en God se koninkryk verbind is. In sy artikel, 'Koninkryk, Verbond en Menseregte' vanuit die dogmatiese of etiese dissipline, skryf Koos Vorster oor menseregte wat op die openbaringsgeskiedenis gebaseer is. Uit 'n hermeneutiek van vertroue word die konsepte koninkryk en verbond as grondslag vir 'n Christelike teorie van menseregte sowel as wetlike en morele menseregte gebruik. Die argument in hierdie artikel is dat albei konsepte, koninkryk en verbond, hoofsaaklik oor geregtigheid en verhoudings tussen God en mens, mens en mens, en mens en skepping handel. Hierdie verhoudings is die kern van menseregte.

Vanuit die pastorale teologie is daar drie kontekstuele artikels in die bundel opgeneem wat op Afrika gerig is. In Amanda du Plessis se artikel, 'The cultural aspect in the contextualisation of pastoral caregiving ministry', word aandag gegee aan die verweefdheid wat Christenskap met die verskillende kulture in Suid-Afrika het. Die aanpasbaarheid en/of onaanpasbaarheid van die Westerse en Afrikakultuur word bespreek en die artikel word afgesluit met die beginsels van 'n Christelike kultuur en die implikasies hiervan vir pastorale berading. In sy artikel, 'Brothers and sisters, can you hear us? Remarks on facilitating a productive dialogue between the Western and African notions of practical theology in light of the decolonisation discourse', gee Alfred Brunsdon 'n oorsig oor Lartey se werk Postcolonializing God - An African practical theology (2013). Sy bevinding is dat dekolonisering 
stremmend op 'n Westerse praktiese teologie inwerk terwyl dit geloofwaardigheid aan die Afrika praktiese teologie verleen. Die artikel stel 'n interkontekstuele dialoog voor met Esther Acolatse se pastorale hermeneutiek as maatstaf vir die dialoog. Die derde artikel in hierdie vakgroep, 'Competing with Christ? A critical Christological analysis of the reliance on Pentecostal prophets in Zimbabwe', is dié van Vhumani Magezi \& Collium Banda. Die dominerende middelaarsrol van die Pentakostalistiese profete in die Zimbabwe-konteks word vanuit 'n Christologiese perspektief beskryf. In plaas van om mense na Christus te lei vir geestelike sekerheid, doen Pentakostalistiese profete van die voorspoedsteologie hulleself as persone met uitnemende geestelike gesag voor waarop mense moet vertrou. Hierdie profete stel hulleself voor as unieke gesalfdes van God wat nader aan Hom is as die gewone gelowiges en dus geestelike gesag en mag oor gelowiges het. Hierdie artikel wil gelowiges bemagtig om hulleself van hierdie profete en hulle versteurde beeld van Christus te distansieer.

Die laaste twee artikels is vanuit 'n Nuwe-Testamentiese perspektief geskryf. In 'A fruitful missional exegesis for a missional hermeneutic and missiology' deur Timothy van Aarde en Fohle Lygunda Li-M word 'n missiologiese eksegese beskryf waarin die teks en konteks verweef is. Die vertrekpunt van hierdie artikel is dat teks en konteks saam die missionêre strategie moet bepaal sonder dat die teks of die konteks ten koste van die ander beklemtoon word. Laastens omskryf George Lotter en Timothy van Aarde die belangrike herontdekking van die gelowiges se priesterskap vir die deelname aan die missio Dei in die artikel getiteld 'A rediscovery of the priesthood of believers in Ephesians 4:1-16 and its relevance for the Missio Dei and a biblical missional ecumenism'. Hierdie artikel loop op die spoor van gelowiges se herontdekking van priesterskap deur verskillende denominasies met die bybelse begronding in Efesiërs 4 en ander Skrifgedeeltes.

Ten slotte: Dankie aan elke outeur wat aan die publikasie deelgeneem het en op hierdie manier erkenning aan Sarel van der Merwe gee vir sy werk in God se koninkryk en sy deelname aan die missio Dei. Dit is my gebed dat hierdie artikels andere sal inspireer om met nog meer oorgawe en ywer aan die missio Dei deel te neem. 'Die oes is groot en die arbeiders is min'.

\section{Soli Deo Gloria.}

